\title{
Xanthan Biosynthesis by Xanthomonas campestris ATCC 13951 on Wastewaters from White Grape Processing
}

\author{
Zorana Rončević · Ida Zahović* · Siniša Dodić · Jovana Grahovac · Jelena Dodić
}

University of Novi Sad, Faculty of Technology Novi Sad, Department of Biotechnology and Pharmaceutical Engineering, Bulevar cara Lazara 1 21000 Novi Sad, Serbia

\begin{abstract}
Summary: Wastewaters from grape processing in wineries are characterized by large seasonal fluctuations in volume and composition, and are often discarded into environment with little or no treatment. The biotechnological production of valuable products is the most promising alternative for reducing the negative environmental impact and recycling these effluents. Results from previous study show that mixed winery wastewaters, after additional optimization of the medium preparation, may be a suitable raw material for industrial xanthan production. Therefore, the aim of this work was to examine the possibility of xanthan production by Xanthomonas campestris ATCC 13951 on mixed wastewaters from different stages of white grape processing in winery with initial sugars content of $20 \mathrm{~g} / \mathrm{L}$. In addition to the media characteristics and indicators of biopolymer quality, raw xanthan yield and degree of sugars conversion into product were determined in order to examine the success of performed bioprocess. The results for biopolymer yield $(14.66 \mathrm{~g} / \mathrm{L})$ and sugars conversion into desired product $(70.21 \%)$ obtained in applied experimental conditions confirm that wastewaters from white grape processing have a great potential to be used as a substrate for xanthan biosynthesis.

Key words: grape, processing, wastewaters, xanthan, Xanthomonas campestris
\end{abstract}

\section{Introduction}

Wineries, distilleries and other grape processing industries annually generate large volumes of waste streams. The resulting wastewaters mainly originate from the operations such as washing of grapes, work surfaces, equipment (crushers, presses, etc.), fermentation tanks, barrels, containers and cooling systems. The composition and quantity of these effluents generated in wineries are different between them and may also vary within the same winery from year to year. The amount of discharged wastewaters and degree of their contamination vary during the year and depend on the operating time period (harvesting, decanting, bottling), the size of the winery and the applied technological procedure (production of white, rose, red or special types of wines) (Brito et al., 2007; Serrano et al., 2011).

Winery wastewaters are characterized by acidic $\mathrm{pH}$ values, high concentration of biodegradable organic matters which mainly originate from seeds, epidermis and yeast, variable content of suspended solids, macronutrients, micronutrients and heavy metals, filtering materials and cleaning agents. Moreover, winery wastewaters contain main components of grapes

Corresponding author: idaidaza@gmail.com and wines such as sugars, nitrogen, phosphorus, alcohols, organic acids, polyphenols, tannins and lignin (Agustina et al., 2008).

According to Statistical Office of the Republic of Serbia the total annual production of grapes in the Republic of Serbia is about 150 thousand tons, while the total area of vineyards is about 22 thousand hectares. The amount of produced wine is variable from year to year, and the average value is about 125 thousand hectoliters. It is estimated that wineries produce between 1.3 and 1.5 $\mathrm{kg}$ of waste residues per liter of wine produced, $75 \%$ of which is wastewater (Lucas et al., 2010). Considering that, it is evident that the non-negligible amounts of effluents are generated in our country with a notable environmental impact. The disposal of winery effluents in creeks, rivers and on soils represents enormous environmental risk.

There are several methods for degradation of pollutants contained in winery wastewaters that have been proposed by many authors. The main disadvantage of usually used treatments is the accumulation of another waste, such as sludge (Ganesh et al., 2010). Therefore, the most promising option for winery wastewaters treatment is microbial production of useful products.

In previous studies it has been confirmed that xanthan can be produced by cultivation of Xanthomonas campestris on wastewaters from different stages of rose (Rončević et al., 2015) and white (Bajić et al., 2015) wine production, as well as their mixtures (Rončević et al., 2017). Xanthan is 
extracellular heteropolysaccharide and commercially most important biopolymer. Due to its rheological properties, xanthan is used in food, pharmaceutical, petrochemical, cosmetic and other industries as a stabilizer, emulsifier, gelling and thickening agent (García-Ochoa et al., 2000).

The aim of this work was to examine the possibility of xanthan production using reference strain Xanthomonas campestris ATCC 13951 on mixed wastewaters from different stages of white grape processing in wineries with initial sugars content of $20 \mathrm{~g} / \mathrm{L}$. Process efficacy was estimated based on the raw xanthan yield and degree of sugars conversion into product. The possibility of applying this biotechnological process for treatment of wastewaters from grape processing is estimated based on the degree of nutrient's conversion.

\section{Material and Method}

\section{Producing microorganism}

Xanthomonas campestris ATCC 13951 was used as the producing microorganism in this experiment. The strain of producing microorganism was kept at $4^{\circ} \mathrm{C}$ on yeast maltose (YM) agar medium $(15.0 \mathrm{~g} / \mathrm{L}$ glucose, $3.0 \mathrm{~g} / \mathrm{L}$ yeast extract, $3.0 \mathrm{~g} / \mathrm{L}$ malt extract, $5.0 \mathrm{~g} / \mathrm{L}$ peptone and $20.0 \mathrm{~g} / \mathrm{L}$ agar) and subcultured at monthly intervals.

\section{Cultivation medium}

Wastewaters, obtained from a domestic winery located in vineyards of Fruška Gora, Vojvodina, Serbia, were used as substrates for xanthan production. Liquid effluents from white grape processing were collected during the washing of the crusher, press and tanks after clarification of must, filtered and then analyzed in terms of sugars composition. Based on the obtained results, wastewaters were mixed in order to achieve initial sugars concentration of $20 \mathrm{~g} / \mathrm{L}$. $\mathrm{CaCO}_{3}$ was added to the mixture in concentration of $2 \mathrm{~g} / \mathrm{L}$ and $\mathrm{pH}$ value was adjusted to 7.0 prior to sterilization by autoclaving at $121^{\circ} \mathrm{C}$ and pressure of 2.1 bars for $20 \mathrm{~min}$.

\section{Xanthan production}

The xanthan production was carried out in $7 \mathrm{~L}$ laboratory bioreactor (CH-8604, Chemap AG, Switzerland) with $5 \mathrm{~L}$ of cultivation medium. The bioreactor was equipped with oxygen electrode as well as $\mathrm{pH}$ electrode with integrated temperature sensor. The sterile cultivation medium was inoculated by adding $10 \%$ (v/v) of inoculum prepared by double passaging in aerobic conditions, on $\mathrm{YM}$ broth, at $25^{\circ} \mathrm{C}$ on a laboratory shaker (KS 4000i control, Ika ${ }^{\circledR}$ Werke, Germany) at $150 \mathrm{rpm}$ for $36 \mathrm{~h}$. The biosynthesis was carried out in batch mode under aerobic conditions (air flow rate of $1 \mathrm{vvm}$ in the first $24 \mathrm{~h}$, and $2 \mathrm{vvm}$ afterwards) for $96 \mathrm{~h}$. In the first $24 \mathrm{~h}$, the biosynthesis temperature and agitation rate were $25^{\circ} \mathrm{C}$ and $200 \mathrm{rpm}$, after which they were increased to $30^{\circ} \mathrm{C}$ and 500 rpm, respectively.

\section{Xanthan separation}

The xanthan was recovered from the supernatant of cultivation medium by precipitation with cold $96 \%$ (v/ $\mathrm{v}$ ) ethanol in the presence of the electrolyte $(\mathrm{KCl})$. Supernatant was obtained using an ultracentrifuge (Hettich Rotina $380 \mathrm{R}$, Germany) at $10000 \mathrm{rpm}$ for 10 min. Ethanol was gradually added to the supernatant at constant stirring until the alcohol content in mixture was $60 \%(\mathrm{v} / \mathrm{v})$. A saturated solution of potassium chloride was added in a quantity to obtain a final content of $1 \%(\mathrm{v} / \mathrm{v})$. Obtained mixture was kept at $4{ }^{\circ} \mathrm{C}$ for $24 \mathrm{~h}$ in order to dehydrate the precipitated xanthan, and then centrifuged at $4000 \mathrm{rpm}$ for $15 \mathrm{~min}$ (Tehtnica LC-321, Slovenia). The precipitated biopolymer was dried to constant weight at $60^{\circ} \mathrm{C}$ in order to determine raw xanthan yield. Ethanol used for xanthan precipitation was recycled by distillation.

\section{Analysis of cultivation medium}

The samples of cultivation medium taken in sterile conditions at predetermined time intervals were analyzed in terms of biomass concentration, nutrients content and rheological behavior. In order to determine the amounts of sugars, total and assimilable nitrogen as well as total phosphorus, the separation of the $X$. campestris cells from the cultivation medium samples was carried out by a centrifugation at $10000 \mathrm{rpm}$ for $10 \mathrm{~min}$ (Hettich Rotina 380 $\mathrm{R}$, Germany).

Standard plate count method was used for determination of the number of producing microorganism cells. The medium samples, taken in sterile conditions, were serially diluted in sterile saline solution and plated on YM agar plates which were incubated at $25^{\circ} \mathrm{C}$ for $48 \mathrm{~h}$. Each individual bacterial cell on the plate was grown into a colony, and the number of producing microorganism cells in the cultivation medium was then calculated by multiplying the final number of colonies by the dilution factor.

Sugars content (glucose and fructose) was determined by high pressure liquid chromatography (HPLC). The samples were filtered through a $0.45 \mu$ m nylon membrane (Agilent Technologies Inc, Germany) and then analyzed on the HPLC instrument (Thermo Scientific Dionex UltiMate 3000 series). The HPLC was equipped with a HPG-3200SD/RS pump, WPS-3000(T) SL autosampler (10 $\mu$ l injection loop), ZORBAX NH2 column (250 mm x $4.6 \mathrm{~mm}, 5 \mu \mathrm{m})$ and RefractoMax 520 detector. $75 \%(\mathrm{v} / \mathrm{v})$ acetonitrile was used as eluent with a flow rate of $1.2 \mathrm{~mL} /$ min and an elution time of $20 \mathrm{~min}$ at column temperature of $25^{\circ} \mathrm{C}$.

Standard methods were used to determine contents of total nitrogen and phosphorus, the Kjeldahl method (Herlich, 1990) for nitrogen and the spectrophotometric method (Gales et al., 1966) for phosphorus. The cultivation medium samples were also analyzed in terms of assimilable nitrogen. The assimilable nitrogen, expressed as amino and ammonia nitrogen, was determined by the Formol titration method (Zoecklein et al., 1999). 
The rheological properties of cultivation medium samples were determined using rotational viscometer (REOTEST 2 VEB MLV Prufgerate-Verk, Mendingen, SitzFreitel) with double gap coaxial cylinder sensor system, spindle N. Based on deflection of measuring instrument $(\alpha, \mathrm{Skt})$, shear stress $(\tau, \mathrm{Pa})$ was calculated under defined values of shear rates $(\mathrm{D}, 1 / \mathrm{s})$ using the Eq. (1):

$$
\tau=0.1 \cdot z \cdot \alpha
$$

where $\mathrm{z}$ is the constant with the value $3.08 \mathrm{dyn} / \mathrm{cm}^{2} \cdot \mathrm{Skt}$. The pseudoplastic behavior of the cultivation medium was confirmed by fitting the Ostwald-de-Waelle model to the experimental data evaluated by regression of the power law. The values of the consistency factor $(\mathrm{K}$, $\mathrm{Pa} \cdot \mathrm{s}^{\mathrm{n}}$ ), flow behavior index (n) and determination coefficient $\left(\mathrm{R}^{2}\right)$ were determined by Excel software 2010 and used for calculation of apparent viscosity $\left(\eta_{\mathrm{a}}\right.$, $\mathrm{mPa} \cdot \mathrm{s}$ ) from Eq. (2):

$$
\eta_{\mathrm{a}}=\mathrm{K} \cdot \mathrm{D}^{\mathrm{n}-1}
$$

\section{Analysis of produced xanthan}

The average molecular weight of the produced xanthan was determined by measuring flow time of xanthan solutions in $0.1 \mathrm{M} \mathrm{NaCl}$ using Ubbelhode capillary viscosimeter. The temperature was kept at $25^{\circ}$ $\mathrm{C}$ using a circulatory water bath. The value of the intrinsic viscosity $([\eta], \mathrm{L} / \mathrm{g})$ was determined and applied to calculate the biopolymer average molecular weight $\left(\mathrm{M}_{\mathrm{W}}, \mathrm{g} / \mathrm{moL}\right)$ using the Mark-Houwink type equation (Milas et al., 1985):

$$
[\mathrm{\eta}]=1.7 \cdot 10^{-7} \mathrm{M}_{\mathrm{W}}^{1.14}
$$

Dry matter, and therefore the moisture of xanthan produced in this experiment was determined by the standard drying method at $105^{\circ} \mathrm{C}$ to a constant mass (AOAC, 2000).

The amount of ash was determined by the standard drying method at $550^{\circ} \mathrm{C}$ (AOAC, 2000).

The samples of raw xanthan were also analyzed in terms of total nitrogen content using Kjeldahl method (Herlich, 1990).

\section{Results and Discussion}

In this research, xanthan biosynthesis on mixed wastewaters from different stages of white grape processing was examined. Wastewaters collected in winery during the washing of the crusher, press and tank after clarification of must were used for substrate preparation which included only mixing of the mentioned effluents without dilution with drinking water and addition of any nutrients. Hence, the preparation of cultivation medium based on wastewaters from white grape processing is very simple and also cost -effective because there is no need for consumption of tap water as well as pure chemicals.

The xanthan production was carried out in the laboratory bioreactor under controlled conditions using reference strain Xanthomonas campestris ATCC 13951. During the first $24 \mathrm{~h}$ of cultivation, all process parameters were regulated in order to ensure rapid growth of producing microorganism cells. After that time period the process parameters were regulated to provide intensive xanthan biosynthesis. The course of the xanthan biosynthesis was monitored by analyzing the samples of cultivation medium in terms of the most important parameters for the biotechnological production. Therefore, the concentration of biomass, the content of nutrients, rheological characteristics of cultivation medium, as well as the quantity and quality of the synthesized biopolymer were determined. The results are graphically presented in Figure 1 (a-c).

In order to ensure high efficiency of the examined bioprocess, cell concentration during cultivation should be around $10^{6}-10^{8} \mathrm{CFU} / \mathrm{mL}$. The initial concentration of $X$. campestris cells was $10 \cdot 10^{8} \mathrm{CFU} / \mathrm{mL}$ which is sufficient for the relatively rapid growth of this microorganism from the beginning of cultivation. The changes of the cells concentration during the xanthan biosynthesis on the effluents from the various stages of white grape processing are graphically presented in Figure 1a. Results shown in this figure indicate that the lag phase of the bacterial growth cycle is absent from a growth curve and that an intense cell production occurred until $24 \mathrm{~h}$. The exponential phase was finished up to $36 \mathrm{~h}$ of cultivation after which the microorganism enters a stationary phase of growth. In this phase the number of viable bacterial cells remains the same, and according to literature data the largest amounts of xanthan are usually biosynthesized right at this period (García-Ochoa et al., 2000). During the entire cultivation cell death was not observed which is very important for industrial microbiological production.

Oxygen is very important nutrient because it is a limiting factor for cells growth and xanthan biosynthesis due to its difficult solubility in viscous medium. Considering that metabolic activity of bacteria of the genus Xanthomonas is very dependent on the content of dissolved oxygen, this value was measured during cultivation and obtained results are shown in Figure 1a. At beginning of the bioprocess, dissolved oxygen concentration in cultivation medium was $90.30 \%$. According to the presented results (Figure 1a) content of this nutrient considerably decreased during the first $24 \mathrm{~h}$ of cultivation which may be a consequence of intense growth and reproduction of cells of producing microorganism strain. At the end of aforementioned time period oxygen concentration was about $35.90 \%$. After a change of process conditions, concentration of dissolved oxygen was increased to $95.10 \%$. With further prolongation of the cultivation, oxygen concentration was slowly decreased in cultivation medium to final 
concentration of $60.30 \%$. This value is well above $10 \%$ which represents a critical oxygen level for the successful xanthan biosynthesis (Amanullah et al., 1998).

The contents of carbon, nitrogen and phosphorus as well as their ratio in the cultivation medium is essential for biosynthesis of xanthan and the extracellular heteropolysaccharides, generally (García-Ochoa et al., 2000). The consumption of these important nutrients for xanthan production was examined during the entire cultivation and obtained results are graphically presented on Figure 1b.
The concentration of the carbon source affects the efficiency of xanthan production process. It is reported that glucose concentrations of $10-50 \mathrm{~g} / \mathrm{L}$ are suitable for xanthan production, while the yield of desired product is decreased at higher glucose content (Papagianni et al., 2001). In addition, the results of previous study indicate that media based on mixed winery wastewaters with initial sugars content of $50 \mathrm{~g} / \mathrm{L}$ are not suitable because large amounts of unused sugars compounds remained in media after performed xanthan biosynthesis (Rončević et al., 2017). Therefore, the

a)

b)
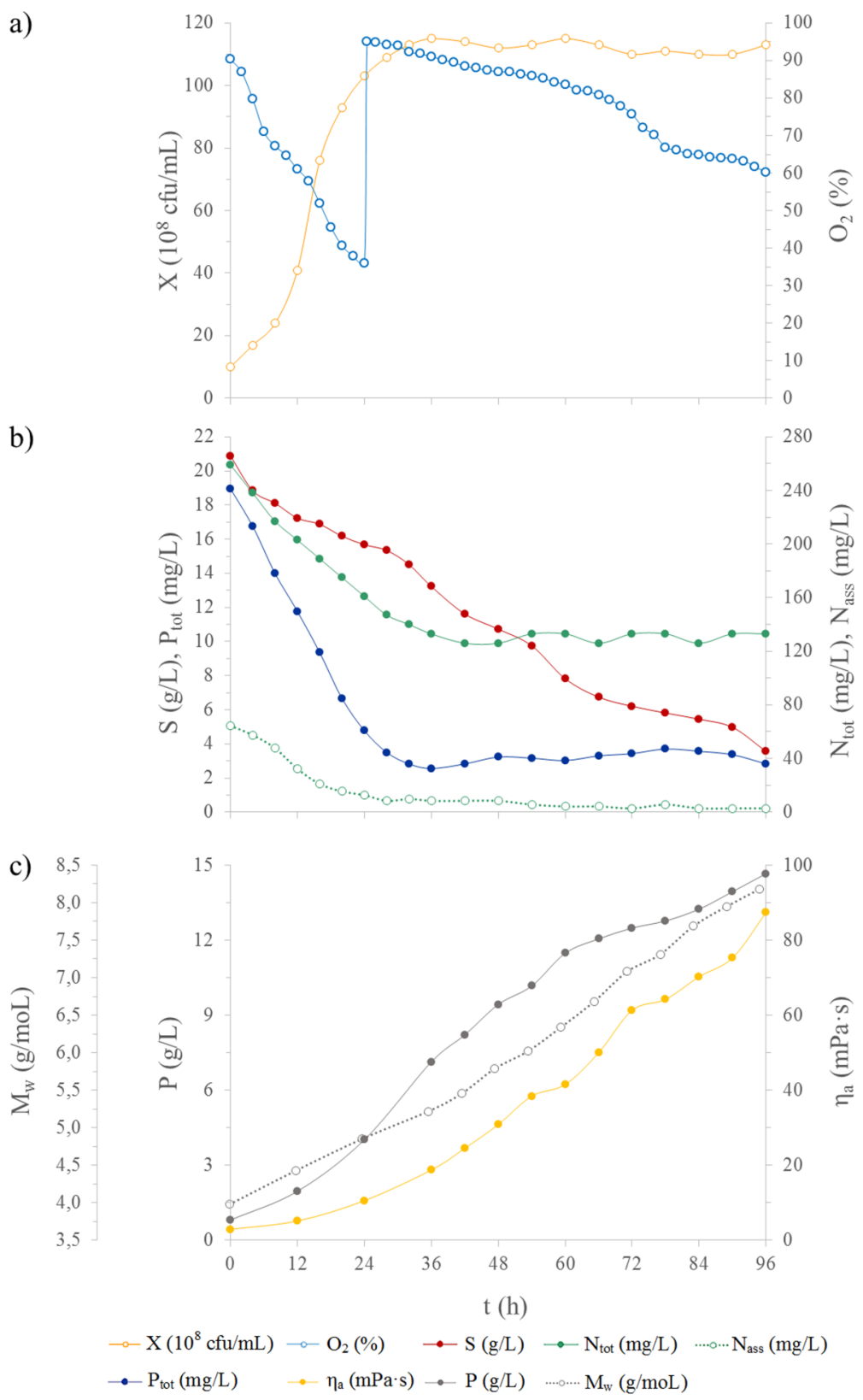

Figure 1. The changes of parameters during the xanthan biosynthesis on wastewaters from white grape processing: a) biomass concentration $(\mathrm{X})$, dissolved oxygen concentration $\left(\mathrm{O}_{2}\right)$; b) sugars content $(\mathrm{S})$, total $\left(\mathrm{N}_{\text {tot }}\right)$ and assimilable $\left(\mathrm{N}_{\text {ass }}\right)$ nitrogen content, total phosphorus content $\left.\left(\mathrm{P}_{\text {tot }}\right) ; \mathrm{c}\right)$ medium apparent viscosity $\left(\eta_{\mathrm{a}}\right)$, raw xanthan yield $(\mathrm{P})$, xanthan molecular weight $\left(\mathrm{M}_{\mathrm{w}}\right)$ 
producing microorganism strain was cultivated on the mixed wastewaters from wine industry with initial sugars content of about $20 \mathrm{~g} / \mathrm{L}(20.88 \mathrm{~g} / \mathrm{L})$. The sugars content, expressed as the sum of glucose and fructose, was determined in samples of cultivation medium and obtained results are shown in Figure 1b. Presented results indicate that sugars content considerably decreased during $96 \mathrm{~h}$ of cultivation, similar to the literature data (Rončević et al., 2017). During the first 24 $\mathrm{h}$ sugars has been mainly used for the growth of $X$. campestris cells (Figure 1a). After that period these compounds was used for maintenance of energy activity of producing microorganism, but also for the xanthan biosynthesis, because the cells were in the stationary phase (Figure 1a) which is characterized by the highest production of this biopolymer. At the end of the bioprocess, residual sugars content in winery wastewater based medium was $3.55 \mathrm{~g} / \mathrm{L}$, thus achieving the sugars conversion of $82.98 \%$, which is even more comparing to previously obtained value of this parameter $(63.53 \%)$ (Rončević et al., 2017). Presented results suggest that in applied experimental conditions the large percentage of sugars compounds from winery wastewaters was utilized on biomass growth and xanthan biosynthesis making this bioprocess cost-effective.

Nitrogen is an essential nutrient that affects the growth of $X$. campestris cells. According to the obtained results (Figure 1b), medium based on wastewaters from white grape processing initially contained total nitrogen in amount of $259 \mathrm{mg} / \mathrm{L}$ and assimilable nitrogen in concentration of $64 \mathrm{mg} / \mathrm{L}$. It is evident that content of total nitrogen was considerably higher than the assimilable nitrogen. Of the total nitrogen in the substrates only about $20 \%$ was assimilable. However, from the results shown in Figure $1 \mathrm{~b}$ it can be seen that during the first $24 \mathrm{~h}$ of cultivation total and assimilable

Table 1. Rheological parameters and coefficient of determination for cultivation medium during xanthan biosynthesis

\begin{tabular}{llll}
\hline Time $[\mathrm{h}]$ & $\mathrm{n}[1]$ & $\mathrm{K}\left[\mathrm{Pa} \cdot \mathrm{s}^{\mathrm{n}}\right]$ & $\mathrm{R}^{2}$ \\
\hline 0 & 0.6771 & 0.0146 & 0.9825 \\
12 & 0.6431 & 0.0305 & 0.9842 \\
24 & 0.5208 & 0.1150 & 0.9921 \\
36 & 0.4808 & 0.2491 & 0.9980 \\
42 & 0.4145 & 0.4534 & 0.9960 \\
48 & 0.4117 & 0.5786 & 0.9973 \\
54 & 0.4052 & 0.7439 & 0.9944 \\
60 & 0.3601 & 1.0069 & 0.9928 \\
66 & 0.3557 & 1.2393 & 0.9967 \\
72 & 0.3493 & 1.5684 & 0.9989 \\
78 & 0.3389 & 1.7304 & 0.9981 \\
84 & 0.3363 & 1.9177 & 0.9994 \\
90 & 0.3346 & 2.0726 & 0.9938 \\
96 & 0.3192 & 2.5962 & 0.9986 \\
\hline
\end{tabular}

nitrogen content in cultivation medium were reduced for $98.00 \mathrm{mg} / \mathrm{L}$ and $51.80 \mathrm{mg} / \mathrm{L}$, respectively, which indicate that $X$. campestris cells in applied experimental conditions do not metabolize only amino and ammonia nitrogen compounds. With further prolongation of cultivation time the changes in the content of nitrogen were very low. These results were expected because the cells were in the stationary growth phase (Figure 1a). After $96 \mathrm{~h}$ of cultivation contents of total and assimilable nitrogen were $133.00 \mathrm{mg} / \mathrm{L}$ and $2.80 \mathrm{mg} / \mathrm{L}$, while conversions rate were $48.65 \%$ and $95.65 \%$, respectively. Despite the fact that assimilable nitrogen content was higher (about 30\%) in winery wastewaters used in previous research (Rončević et al., 2017), a larger conversions of total and assimilable nitrogen were achieved in this experiment.

Phosphorus is an essential nutrient required for proper cell functioning and for making ATP (adenosine triphosphate), a molecule which provides energy to living cells (Butusov and Jernelöv, 2013). Cultivation medium based on effluents from white grape processing initially contained total phosphorus in amount of 18.96 $\mathrm{mg} / \mathrm{L}$. From the results shown in Figure $1 \mathrm{~b}$ it can be seen that during the first $24 \mathrm{~h}$ of cultivation, when the growth of biomass was the most intensive (Figure 1a), total phosphorus content in cultivation medium was considerably decreased. After mentioned time period content of this nutrient was $4.77 \mathrm{mg} / \mathrm{L}$. With further prolongation of the cultivation, the total phosphorus concentration slowly decreased in medium. At the end of the bioprocess, phosphorus content was $2.82 \mathrm{mg} / \mathrm{L}$ and achieved value of its conversion was $85.11 \%$. The change of total phosphorus content have shown identical trend as in literature data (Rončević et al., 2017), where the conversion of total phosphorus compounds was also high $(79.16 \%)$

Due to the fast response and simplicity of the measurement, the xanthan quantity is estimated by changes of the cultivation medium viscosity (Salamone, 1996). Therefore, the amount of xanthan produced in applied experimental conditions was evaluated based on the rheological behavior of samples of the cultivation medium. The rheological parameters were determined from the relationship between shear rate and shear stress. The obtained values of consistency factor ( $\mathrm{K}$, $\mathrm{Pa} \cdot \mathrm{s}^{\mathrm{n}}$ ), flow behavior index (n) and coefficient of determination $\left(\mathrm{R}^{2}\right)$ are presented in Table 1 .

Flow behavior index represents a level of deviation from Newtonian flow behavior. The rheological measurement showed that all cultivation medium samples had pseudoplastic properties, a known characteristic of xanthan solutions (García-Ochoa et al., 2000 ), because the values of flow behavior index were 0 $<\mathrm{n}<1$. The values of this parameter decreased from 0.6771 to 0.3192 which indicated that during the cultivation pseudoplastic characteristics of medium became more pronounced. Also, the Ostwald-de-Waele model showed a good agreement with the experimental 
Table 2. Properties of commercial and raw xanthan

\begin{tabular}{lcc}
\hline Property & Commercial xanthan & Raw xanthan \\
\hline Physical state & Dry, cream-colored powder & Dry, cream-colored powder \\
Moisture $(\%)$ & $8.00-15.00$ & 9.13 \\
Ash $(\%)$ & $7.00-12.00$ & 23.33 \\
Nitrogen $(\%)$ & $0.30-1.00$ & 4.05 \\
\hline
\end{tabular}

data, since the coefficients of determination were higher than 0.98 in all tests. Consistency factor is proportional to the viscosity, and increase of this parameter shown in Table 1 indicates an increase in the amount of xanthan in cultivation medium during the bioprocess.

Xanthan biosynthesis during the bioprocess was monitored by determination of apparent viscosity of the cultivation medium and the calculated results are shown in Figure 1c. According to the graphically presented results, apparent viscosity of cultivation medium increased significantly after $24 \mathrm{~h}$ of cultivation as expected, because after this time period the cells slowly entered the stationary phase (Figure 1a). Maximal values of apparent viscosity of medium was reached in $96 \mathrm{~h}$ of cultivation and amounted $87.35 \mathrm{mPa} \cdot \mathrm{s}$. The viscosity of xanthan solutions strongly depends on its concentration and also on the chains length which is characteristic of applied producing microorganism, medium composition as well as the process parameters (Casas et al., 2000; García-Ochoa et al., 2000). With this in mind the quality and the quantity of produced xanthan were determined during the entire bioprocess.

Based on results shown in Figure 1c, it can be seen that during the first $24 \mathrm{~h}$ of cultivation xanthan was biosynthesized in small quantity, and after that period of time the amount of produced xanthan was considerably increased. The raw xanthan yield and degree of sugars conversion into product were selected as indicators of efficacy of xanthan production on mixed wastewaters from white grape processing. At the end of the bioprocess xanthan yield of $14.66 \mathrm{~g} / \mathrm{L}$ was achieved. This indicates that in applied experimental conditions the $70.21 \%$ of sugars compounds were converted into desired product which is in accordance with the literature data (Rosalam and England, 2006). Comparing to results of study conducted by Rončević et al. (2017), it can be noticed that the sugars conversion into product achieved in this experiment was significantly higher.

The average value of molecular weights was determined as an indicator of the quality of raw xanthan produced in the applied experimental conditions, and the obtained results are shown in Figure 1c. From the presented results it can be seen that molecular weight of xanthan was considerably increased during the cultivation which can be a consequence of molecular crosslinking by divalent ions from the medium $\left(\mathrm{Ca}^{2+}\right)$ due to pyruvate and acetate groups in the molecule. At the end of biosynthesis, molecular weight of xanthan produced on medium based on wastewaters from white grape processing was $8.18 \cdot 10^{5} \mathrm{~g} / \mathrm{mol}$.
Besides molecular weight, there are other typical properties of xanthan gum that are very important to determine its practical application. Therefore, raw xanthan separated from the cultivation medium was analyzed in terms of physical state, moisture, ash and nitrogen content. The obtained results and values of mentioned parameters for commercial xanthan (GarcíaOchoa et al., 2000) are given in Table 2. Physical state and value of moisture content of raw xanthan are in the normal range, but there are some differences in ash and nitrogen content between commercial and raw xanthan. Differences in values of these parameters may be caused by the type of producing microorganism, composition of cultivation medium and the degree of purification of the biopolymer.

The results obtained in this study indicate that xanthan biosynthesis on wastewaters from white grape processing in winery with initial sugars content of $20 \mathrm{~g} /$ $\mathrm{L}$ was successfully performed. In addition, this bioprocess can find important applications in the biological purification of winery wastewaters since the concentrations of the most important nutrients which contribute to its pollution were considerably reduced.

\section{Conclusions}

In this research the possibility of xanthan production using reference strain Xanthomonas campestris ATCC 13951 on mixed wastewaters from different stages of white grape processing was examined. Wastewaters from winery collected during the washing of crusher, press and tank after must clarification were mixed to achieve initial sugars content of $20 \mathrm{~g} / \mathrm{L}$ and used as cultivation medium. Process efficacy was estimated based on the raw xanthan yield and degree of sugars conversion into product. In applied experimental conditions, xanthan was produced in amount of $14.66 \mathrm{~g} / \mathrm{L}$ wherein the degree of sugars conversion into product was $70.21 \%$. These results indicate that wastewaters from grape processing in winery have a great potential to be used as substrates in the biotechnological xanthan production. The degree of conversions of sugars $(82.98 \%)$, total nitrogen $(48.65 \%)$ and phosphorus $(85.11 \%)$ suggest the possibility of application of this bioprocess in a biological purification of winery wastewaters. It may be considered that the use of these effluents in xanthan biosynthesis would reduce the production costs and environmental problems caused by disposal of waste streams generated during grape processing in wineries and other industries. 


\section{References}

Agustina, T.E., Ang, H.M., Pareek, V.K. (2008). Treatment of winery wastewater using a photocatalytic/photolytic reactor. Chemical Engineering Journal, Volume 135 (1-2), 151-156. doi:10.1016/ j.cej.2007.07.063

Amanullah, A., Tuttiett, B., Nienow, A.W. (1998). Agitator Speed and Dissolved Oxygen Effects in Xanthan Fermentations. Biotechnology and Bioengineering 57, 198-210.

AOAC. (2000) Official methods of analysis of AOAC. International 17th edition, Gaithersburg, MD, USA Association of Analytical Communities.

Bajić B., Rončević, Z., Puškaš, V., Miljić, U., Dodić, S., Grahovac, J., Dodić, J. (2015). White wine production effluents used for biotechnological production of xanthan. Journal on Processing and Energy in Agriculture, 19 (1), 52-55.

Brito, A.G., Peixoto, J., Oliveira, J.M., Oliveira, J.A., Costa, C., Nogueira, R., Rodrigues, A. (2007). Brewery and winery wastewater treatment: Some focal points of design and operation. In: Oreopoulou, V., Russ, W. Utilization of By-Products and Treatment of $W$ aste in the Food Industry, ISEKI-Food, Springer Science, New York, 109-133.

Butusov, M., Jernelöv A. (2013). Phosphorus in the Organic Life: Cells, Tissues, Organisms. In: Phosphorus Volume 9, Springer, New York, 13-17.

Casas, J.A., Santos, V.E., García-Ochoa, F. (2000). Xanthan gum production under several operational conditions:molecular structure and rheological properties. Ensyme and Microbial Technology 26, 282-291.

Gales, M.E.Jr., Julian, E.C., Kroner, R.C. (1966). Method for quantitative determination of total phosphorus in water. American Water Works Association Volume 58 (10), 1363-1368.

Ganesh, R., Rajinikanth, R., Thanikal, J.V., Ramanujam, R.A., Torrijos, M. (2010). Anaerobic treatment of winery wastewater in fixed bed reactors. Bioprocess and Biosystems Engineering, Volume 33 (5), 619-628. DOI:10.1007/s00449-009-0387-9
García-Ochoa, F., Santos, V.E., Casas, J.A., Gómez, E. (2000). Xanthan gum: production, recovery, and properties. Biotechnology Advances, Volume 18 (7), 549-579.

Herlich, K. (1990). Official Methods of Analysis of the Association of Official Analytical Chemists, 5th edition, Association of Official Analytical Chemists, Arlington, 17-19.

Lucas, M.S., Peresa, J.A., Pumab, G.L. (2010). Treatment of winery wastewater by ozone-based advanced oxidation processes $(\mathrm{O} 3, \mathrm{O} 3 /$ $\mathrm{UV}$ and $\mathrm{O} 3 / \mathrm{UV} / \mathrm{H} 2 \mathrm{O} 2)$ in a pilot-scale bubble column reactor and process economics. Separation and Purification Technology 72, 235-241. doi:10.1016/j.seppur.2010.01.016

Milas, M., Rinaudo, M. and Tinland, B. (1985). The viscosity dependence on concentration, molecular weight and shear rate of xanthan solutions. Polymer Bulletin 14 (2) 157- 164. DOI: 10.1007/ BF00708475

Papagianni, M., Psomas, S.K., Batsilas, L., Paras, S.V., Kyriakidis, D.A., Liakopoulou-Kyriakides, M. (2001). Xanthan production by Xanthomonas campestris in batch cultures. Process Biochemistry Volume 37, 73-80.

Rosalam, S., England, R. (2006). Review of xanthan gum production from unmodified starches by Xanthomonas comprestris sp., Ensyme and Microbial Technology Volume 39 (2), 197-207. DOI: 10.1016/ j.enzmictec.2005.10.019

Rončević, Z., Bajić, B., Grahovac, J., Dodić, S., Miljić, U., Puškaš, V., Dodić, J. (2015). Wastewaters from rose wine production as substrate for xanthan production. International Journal of Environmental Engineering IJEE, Volume 2 (2), 150-153.

Rončević, Z., Bajić, B., Vučurović, D., Dodić, S., Grahovac, J., Dodić, J. (2017). Xanthan production on wastewaters from wine industry. Hemijska industrija. Volume 71 (2), 145-153.

Salamone, J.C. (1996). Polymeric materials encyclopedia. CRC Press Inc., Florida, USA

Serrano, L., de la Varga, D., Ruiz, I., Soto, M. (2011). Winery wastewater treatment in a hybrid constructed wetland. Ecological Engineering, Volume 37 (5), 744-753. doi:10.1016/j.ecoleng.2010.06.038

Zoecklein, B.W., Fugelsang, K.C., Gump, B.H., Nury, F., (1999). Wine Analysis and Production, Kluwer Academic, New York.

\section{Biosinteza ksantana primenom Xanthomonas campestris ATCC 13951 u otpadnim vodama iz prerade belog grožđa}

\section{Zorana Rončević · Ida Zahović · Siniša Dodić · Jovana Grahovac · Jelena Dodić}

Sažetak: Otpadne vode nastale tokom prerade grožđa u vinarijama karakterišu velike sezonske varijacije u zapremini $i$ sastavu, a obično se ispuštaju u životnu sredinu sa malo ili bez prethodnog tretmana. Biotehnološka proizvodnja visokovrednih proizvoda trenutno je najperspektivnija alternativa za smanjenje negativnog uticaja na životnu sredinu i reciklažu pomenutih efluenata. Rezultati prethodnih istraživanja pokazuju da namešane otpadne vode vinarija, nakon dodatne optimizacije pripreme medijuma, mogu biti pogodne sirovine za industrijsku proizvodnju ksantana. Stoga je ovaj rad izveden sa ciljem ispitivanja mogućnosti proizvodnje ksantana primenom soja Xanthomonas campestris ATCC 13951 na namešanim otpadnim vodama iz različitih faza prerade belog grožđa u vinariji sa početnim sadržajem šećera od $20 \mathrm{~g} / \mathrm{l}$. Osim karakteristika medijuma i pokazatelja kvaliteta biopolimera, određivani su prinos sirovog ksantana i stepen konverzije šećera u proizvod kako bi se procenila efikasnost izvedenog bioprocesa. Rezultati koji se odnose na prinos biopolimera (14,66 g/l) i stepen konverzije šećera u željeni proizvod (70,21\%), a ostvareni su u primenjenim eksperimentalnim uslovima, potvrđuju da otpadne vode iz prerade belog grožđa imaju veliki potencijal za primenu kao supstrata za biosintezu ksantana.

Ključne reči: grožđe, ksantan, otpadne vode, prerada, Xanthomonas campestris 